\title{
KEBIJAKAN PENENTUAN BENTUK INSENTIF PENGEMBANGAN HUTAN RAKYAT DI WILAYAH GUNUNG SAWAL, CIAMIS DENGAN METODA AHP ${ }^{1}$ (Policy to Determine Incentived form for Developing Privately Owned Forest in Gunung Sawal, Ciamis District with AHP Method)
}

\author{
Oleh/By : \\ Dian Diniyati² \& San Afri Awang ${ }^{3}$ \\ Balai Penelitian Kehutanan Ciamis \\ Jl. Raya Ciamis Banjar Km 4 dsn Pamalayan Ciamis \\ No.telp.081546815496 Alamat e-mail dian_diniyati@yahoo.com
}

\begin{abstract}
Forest area in Gunung Sawal was divided into several classifications, i.e. Suaka Margasatwa Gunung Sawal (SMGS) managed by BKSDA Jawa Barat II, production forest managed by Perum Perbutani and privately owned forest managed by community. There was one ecosystem, influence to areas aside. anotherhand privately owned forests were continuously converted into other functions. To keep them settled need incentives. The purpose of the research was to find out the trigger factors in the changing of land utilization in privately owned forest and the forms of incentives fit to corresponding community socio-economics. The research was conducted in Sandingtaman village, Panjalu sub-district, Ciamis district from September to October 2008. Analytical Hierarchy Process (AHP) and in-depth interview techniques were implemented to collect data from key persons and farmers. Data collected, moreover, were descriptively analyzed. The result showed that socio-economic conditions influenced the farmer's decision in managing their privately owned forest. Incentives form elected were 9 and according to the key persons preferences, have selected 3 possessed of high score i.e. relevance and continuously extension on these following aspects i.e., technical, management, economic, social and culture (0.167), district government regulations which support land used establishmentprotecting environment and villagers welfare (0.140), fair regulations i.e. pro farmers regulation especially in arranging trade permissions related to wood species (0.126).
\end{abstract}

Keywords: Private owned forest, Gunung Sawal, farmer, keyperson, incentive.

\begin{abstract}
ABSTRAK
Kawasan hutan Gunung Sawal terbagi menjadi beberapa klasifikasi, diantaranya Suaka Margasatwa Gunung Sawal (SMGS) dikelola BKSDA Jawa Barat II, hutan produksi dikelola Perum Perhutani, dan hutan rakyat dimiliki masyarakat. Ketiganya merupakan satu kesatuan ekosistem, dan keberadaannya berpengaruh terhadap wilayah yang ada di sekitarnya. Namun hutan rakyat terus mengalami konversi lahan menjadi fungsi lainnya. Untuk mempertahankannya, diperlukan insentif. Tujuan penelitian menemukan faktor-faktor penyebab terjadinya perubahan lahan di hutan rakyat serta
\end{abstract}

\footnotetext{
${ }^{1}$ Tulisan merupakan bagian dari Tesis Dian Diniyati

${ }^{2}$ Peneliti Pada Balai Penelitian Kehutanan Ciamis

${ }^{3}$ Guru Besar Pada Universitas Gadjah Mada Jogyakarta
} 
bentuk insentif yang sesuai dengan kondisi sosial ekonomi masyarakat. Kegiatan ini dilaksanakan di Desa Sandingtaman, Kecamatan Panjalu, Kabupaten Ciamis, pada bulan September - Oktober 2008. Data dikumpulkan dari responden petani dan informan kunci, dengan tehnik wawancara mendalam (indepth interview) dan metoda AHP (Analitical Hierarchy Process), selanjutnya dianalisis secara deskriptif. Kondisi sosial ekonomi mempengaruhi keputusan petani dalam pengelolaan hutan rakyatnya. Dari 9 bentuk insentif yang terpilih selanjutnya berdasarkan preferensi informan kunci, terpilih 3 insentif yang memiliki nilai tertinggi yaitu Penyuluhan yang tepat dan berlanjut baik tentang aspek teknis maupun manajemen, ekonomi, sosial, budaya $(0,167)$; Perda yang mendukung kemantapan tata guna lahan yang melindungi lingkungan dan kesejahteraan masyarakat desa, $(0,140)$; dan Regulasi yang dapat memberikan keadilan, yaitu peraturan pemerintah yang lebih berpihak kepada petani, misalnya pengaturan perizinan bertata niaga kayu yang berkaitan dengan jenis tanaman $(0,126)$.

Kata kunci: Hutan rakyat, Gunung Sawal, petani, informan kunci, insentif

\section{PENDAHULUAN}

\subsection{Latar Belakang}

Hutan adalah sumber daya alam yang bisa diperbaharui, merupakan modal pembangunan yang jika dikelola secara benar akan memberi manfaat ekonomi, melalui penciptaan lapangan kerja dengan tetap menjaga manfaat lingkungannya. Sumber daya hutan Indonesia saat ini meliputi hutan produksi (66,35 juta ha), hutan lindung (33,5 juta ha), dan hutan konservasi (20,5 juta ha) dengan total luas mencapai 120,35 juta ha (Purnama, 2009).

Menurunnya kemampuan pasokan kayu dari hutan alam dan belum optimalnya hasil pembangunan hutan tanaman, menyebabkan hasil hutan dari hutan rakyat menjadi pilihan penting. Hutan di Kabupaten Ciamis, berdasarkan status kepemilikannya terdiri dari hutan negara dengan luas 35.007,88 ha dan hutan rakyat sekitar 27.945 ha. Produksi hutan rakyat rata-rata per tahun antara $300.000 \mathrm{~s} / \mathrm{d} 400.000 \mathrm{~m}^{3}$, atau setara $4,9 \%$ dari jatah produksi tebangan (JPT) nasional dari hutan alam yang ditetapkan pemerintah yakni $8.152 .250 \mathrm{~m}^{3}$ (Anonimous, 2009). Sementara produksi kayu dari hutan negara yang dikelola Perum Perhutani KPH Ciamis tertinggi hanya mencapai 67.548,63 $\mathrm{m}^{3}$ (Dinas Kehutanan Ciamis, 2006). Tingginya potensi hutan rakyat di Ciamis tersebut mencerminkan tingginya manfaat ekonomi, sekaligus memberi gambaran tingginya potensi lapangan kerja yang juga bisa diciptakan, seperti industri pengolahan kayu berbasis kayu rakyat. Ini menunjukkan bahwa peran hutan rakyat mulai dirasakan penting bagi kehidupan masyarakat, sehingga menumbuhkan minat sebagian besar masyarakat mengembangkan tanaman sengon secara swadaya, serta makin banyaknya industri penggergajian. Dibuktikan dengan menaiknya minat menanam dari tahun 2006 sebanyak 2.561.728 batang menjadi 6.304.920 batang pada tahun 2007, sementara pemerintah hanya mampu menanam 415.000 batang pada tahun 2006 kemudian 873.492 batang pada tahun 2007 (Dinas Kehutanan Ciamis, 2006).

Pada sisi yang lain, perkembangan hutan rakyat menghadapi banyak kendala dan ancaman, diantaranya sangat sensitifnya usaha hutan rakyat terhadap pengaruh-pengaruh yang mengarah kepada konversi usaha lainnya, yang disebabkan kebutuhan lahan untuk pemukiman, usaha tani di luar sektor kehutanan dan kontinyuitas pengembangan hutan 
rakyat (Herawati, 2001). Di wilayah hutan Gunung Sawal, telah terjadi perubahan lahan kebun/hutan rakyat menjadi penggunaan lain selama kurun waktu tujuh tahun (tahun 1996 - 2003) seluas 546,39 ha (78,056 ha/tahun). Perinciannya sebagai berikut: perubahan menjadi pemukiman seluas 271,35 ha dan menjadi pertanian lahan basah seluas 275,04 ha. Namun ternyata, terjadi konversi sebaliknya yaitu dari lahan sawah menjadi pertanian lahan kering yang cukup luas yakni 304,49 ha (Diniyati, et al. 2006). Perubahan lahan tersebut akan menurunkan nilai manfaat ekologi (pengatur tata air. pengendali erosi, peredam limpasan permukaan dan pengatur kesuburan tanah).

Berkenaan dengan hal tersebut, perlu dilakukan analisis mengenai bentuk insentif yang efektif, yang diperuntukkan bagi kawasan hulu, terutama untuk petani pemilik hutan rakyat, sebagai bentuk kompensasi pengembangan hutan rakyat dengan prioritas menjaga fungsi ekologi dan fungsi ekonomi.

\subsection{Tujuan Penelitian}

Penelitian ini bertujuan untuk:

1. Menemukan faktor-faktor penyebab terjadinya perubahan penggunaan lahan.

2. Mendapatkan bentuk insentif pengembangan hutan rakyat yang sesuai dengan kondisi lingkungan agar dicapai kelestarian pendapatan dan kelestarian lingkungan.

\section{BAHAN DAN METODA PENELITIAN}

\subsection{Lokasi dan Waktu Penelitian}

Penelitian dilakukan di Desa Sandingtaman, Kecamatan Panjalu, Kabupaten Ciamis, Jawa Barat. Pelaksanaannya pada bulan September - November 2008.

\subsection{Pengambilan Contoh Penelitian}

Unit analisis yang dijadikan responden yaitu: 1) petani hutan rakyat anggota kelompok tani di Desa Sandingtaman. Dipilih secara acak sederhana (simple random sampling), sebanyak 34 orang, 2) Informan kunci (narasumber Stakeholders) dipilih secara sengaja (purposive sampling), sebanyak 9 orang.

\subsection{Jenis Data}

Jenis data yang dikumpulkan yaitu data primer meliputi data karakteristik petani hutan rakyat dan data preferensi terhadap bentuk insentif hutan rakyat. Data sekunder yang dikumpulkan adalah data dan informasi mengenai kondisi hutan rakyat di Gunung Sawal dan kondisi Desa Sandingtaman, yang berasal dari laporan instansi pemerintahan yang berhubungan dengan tujuan penelitian.

\subsection{Pengumpulan Data}

Pengumpulan data primer dilakukan dengan teknik wawancara mendalam (indepth interview). Dilakukan secara terbuka dan terstruktur, tujuannya supaya dapat diperoleh 
informasi yang lengkap. Teknik wawancara secara terstruktur menggunakan panduan pertanyaan dan daftar pertanyaan yang dipersiapkan terlebih dahulu sebelum melakukan wawancara. Data preferensi stakeholders dikumpulkan dengan teknik AHP. Data sekunder diperoleh melalui studi pustaka (literature review).

\subsection{Analisis Data}

Data yang telah diperoleh diolah dalam bentuk tabulasi atau gambar, sedangkan data bentuk insentif hutan rakyat, digunakan perangkat lunak expert choise 9.0, sehingga dihasilkan bobot prioritas pada setiap bentuk insentif. Selanjutnya seluruh data yang telah diperoleh dianalisis dengan teknik deskriptif.

\section{HASIL DAN PEMBAHASAN}

\subsection{Kondisi Sosial Ekonomi Petani Hutan Rakyat}

Kondisi sosial ekonomi petani hutan rakyat yang ada wilayah Gunung Sawal akan mencerminkan karakteristiknya, seperti tercantum pada Tabel 1.

Tabel 1. Karakteristik Petani Hutan Rakyat

\begin{tabular}{|c|c|c|c|}
\hline No & Karakteristik petani (Farmer characteristics) & Jumlah (Total) & Persentase (Percentage) \\
\hline \multirow[t]{5}{*}{1} & Umur & & \\
\hline & a. $0-14$ & 0 & 0 \\
\hline & b. $15-64$ & 28 & 82,35 \\
\hline & c. 65 up & 6 & 17,65 \\
\hline & Total & 34 & 100 \\
\hline \multirow[t]{7}{*}{2} & Jenis Pekerjaan & & \\
\hline & a. Tani & 28 & 82,35 \\
\hline & b. Peternak ayam & 3 & 8,83 \\
\hline & c. Aparat Desa & 1 & 2,94 \\
\hline & d. Pedagang & 1 & 2,94 \\
\hline & e. Pensiunan & 1 & 2,94 \\
\hline & Total & 34 & 100 \\
\hline \multirow[t]{7}{*}{3} & Tingkat Pendidikan & & \\
\hline & a. Tidak sekolah & 1 & 2,94 \\
\hline & b. SD tidak tamat & 4 & 11,76 \\
\hline & c. SD tamat/ sederajat & 24 & 70,59 \\
\hline & d. SMP/ sederajat & 2 & 5,88 \\
\hline & e. SMA/ sederajat & 3 & 8,83 \\
\hline & Total & 34 & 100 \\
\hline \multirow[t]{4}{*}{4} & Jumlah tanggungan keluarga (orang) & & \\
\hline & a. $0-2$ & 22 & 64,71 \\
\hline & b. $3-5$ & 12 & 35,29 \\
\hline & Total & 34 & 100 \\
\hline \multirow[t]{3}{*}{5} & Rataan pendapatan petani setiap tahun & Rp. $15.089 .849,88$ & 100 \\
\hline & Rataan pengeluaran petani setiap tahun & $\begin{array}{ll}\text { Rp. } & 8.485 .519,41 \\
\end{array}$ & 100 \\
\hline & Saldo pendapatan & Rp. $6.604 .330,47$ & 100 \\
\hline
\end{tabular}

Sumber (Source) : Analisis data primer, 2008 (Primary data analysis, 2008) 
Berdasarkan Tabel 1 di atas diketahui bahwa umur responden tergolong produktif (15 - 64 tahun) sebanyak 82,35\%, lebih banyak dibandingkan dengan umur tidak produktif (lebih dari 65 tahun) sebanyak 17,65\%. Ini menunjukan bahwa petani hutan rakyat adalah orang yang berusia muda dan termasuk dalam kategori kelompok umur produktif. Pada usia ini biasanya orang akan lebih berkreatifitas dan banyak berkarya. Selain itu memperlihatkan juga bahwa kegiatan di bidang pertanian masih menarik minat masyarakat. Hal ini dibuktikan dengan mayoritas responden pekerjaan utamanya adalah sebagai tani ada 23 orang $(67,65 \%)$. Dengan banyaknya minat tenaga produktif di pertanian dan kehutanan, menunjukkan bahwa ketersediaan tenaga kerja untuk sektor pertanian dan kehutanan masih banyak, seperti dikemukakan oleh Purwanto, et al. (2004) dan Awang, et al. (2007) bahwa tenaga kerja yang digunakan dan dimanfaatkan untuk hutan rakyat berasal dari dalam keluarga. Melimpahnya tenaga kerja, mengharuskan tersedianya lapangan pekerjaan, salah satunya adalah bidang pertanian dan kehutanan, dimana sektor ini tidak mensyaratkan adanya kualifikasi tertentu untuk melaksanakan kegiatan pertanian dan kehutanan.

Tingkat pendidikan petani Desa Sandingtaman rata-rata hanya tamat SD atau pernah sekolah di SD tapi tidak selesai $(70,59 \%)$, tingkat pendidikan tertinggi adalah SMA/Sederajat $(8,82 \%)$. Tingkat pendidikan ini berpengaruh terhadap pilihan dan peluang yang dapat diraihnya, sehingga mampu berkreatifitas dan berproduktif untuk berpartisipasi dalam pembangunan di segala bidang, termasuk pembangunan hutan rakyat (Badan Pusat Stataistik Provinsi Jawa Barat, 2007).

Jumlah anggota rumah tangga yang masih menjadi tanggungan dikelompokkan menjadi jumlah tanggungan 2 orang (64,71\%), dan jumlah tanggungan keluarga antara 3 sampai 5 orang $(35,29 \%)$. Anggota keluarga ini merupakan sumber tenaga kerja. Tenaga kerja ini merupakan modal yang dapat dimanfaatkan untuk mengolah lahan yang dimiliki petani (Purwanto, et al., 2004; Awang, et al., 2007). Jumlah tanggungan keluarga ini, berpengaruh terhadap keputusan usaha yang akan dijalankan, agar hasil usahanya dapat mencukupi kebutuhan keluarga.

Rata-rata total pendapatan petani setiap tahunnya adalah Rp. 14.969.880 dengan total pengeluaran petani setiap tahun adalah Rp. 8.485.519,41. Dengan demikian setiap tahun terdapat surplus pendapatan yaitu sebesar Rp. 6.604.330,47. Berarti bahwa total pendapatan lebih besar dari pada total pengeluaran konsumsi rumah tangga petani, dengan kata lain seluruh petani mampu memenuhi kebutuhannya dan bahkan terdapat kelebihan dari pendapatan tersebut, setelah digunakan untuk memenuhi pengeluaran konsumsi rumah tangga.

\subsection{Perubahan Penggunaan Lahan Hutan Rakyat}

Hutan rakyat yang dimiliki oleh petani letaknya terpencar/tidak dalam satu hamparan, rata-rata petani memiliki 2,6 blok, dengan rata-rata luasan setiap blok adalah $21.906,64 \mathrm{~m}^{2}$, dengan total luasnya $5669,89 \mathrm{~m}^{2}$, seperti ditunjukkan oleh Tabel 2. Jarak lahan hutan rakyat dari rumah petani berkisar antara $0,01 \mathrm{~km}-3 \mathrm{~km}$. Kondisi jarak ini mempengaruhi kunjungan petani terhadap lahan hutan rakyatnya. Semakin jauh jaraknya, semakin jarang dikunjungi, sehingga lahan tersebut cenderung ditanami dengan jenis yang 
sama, dan kurang variatif. Sebaliknya, untuk lahan yang berdekatan dengan rumah akan cenderung mudah mengalami perubahan fungsi, tergantung pada informasi terkait jenis tanaman yang diterima petani.

Tabel 2. Kepemilikan Lahan Responden

Table 2. Respondent Land Ownership

\begin{tabular}{|l|r|c|c|c|r|r|r|r|r|r|}
\hline \multirow{2}{*}{$\begin{array}{c}\text { Jenis } \\
\begin{array}{l}\text { Penggunaan } \\
\text { Lahan }\end{array}\end{array}$} & \multicolumn{2}{|c|}{ Warisan } & \multicolumn{2}{c|}{ Beli } & \multicolumn{2}{c|}{ Sewa lahan } & \multicolumn{2}{c|}{ Garapan } & \multicolumn{2}{c|}{ Total Luas } \\
\cline { 2 - 12 } & $\left(\mathrm{m}^{2}\right)$ & $(\%)$ & $\left(\mathrm{m}^{2}\right)$ & $(\%)$ & $\left(\mathrm{m}^{2}\right)$ & $(\%)$ & $\left(\mathrm{m}^{2}\right)$ & $\%$ & $\left(\mathrm{~m}^{2}\right)$ & $\%$ \\
\hline $\begin{array}{l}\text { Hutan } \\
\text { Rakyat }\end{array}$ & 1825,65 & 32,19 & 3844,24 & 70,54 & 0 & 0 & 0 & 0 & 5669,89 & 64,54 \\
\hline Sawah & 867,18 & 40,02 & 1005,53 & 46,41 & 294,12 & 13,57 & 0 & 0 & 2166,83 & 24,67 \\
\hline $\begin{array}{l}\text { Pekarangan } \\
\text { dan Rumah }\end{array}$ & 144,32 & 46,15 & 168,41 & 53,85 & 0 & 0 & 0 & 0 & 312,73 & 3,56 \\
\hline Kolam Ikan & 49,21 & 20,55 & 190,24 & 79,45 & 0 & 0 & 0 & 0 & 239,45 & 2,73 \\
\hline $\begin{array}{l}\text { Lainnya } \\
\text { PHBM dan } \\
\text { lahan } \\
\text { terlantar })\end{array}$ & 0 & 0 & 168,82 & 42,71 & 0 & 0 & 226,47 & 57,29 & 395,29 & 4,5 \\
\hline Total & 2886,36 & 32,86 & 5377,24 & 61,21 & 294,12 & 3,35 & 226,47 & 2,58 & 8784,19 & 100 \\
\hline
\end{tabular}

Sumber (Source) : Analisis data primer, 2008 (Primary data analysis, 2008)

Luas lahan untuk hutan rakyat menempati urutan pertama, kondisi ini memberikan peluang cukup besar untuk pengembangan hutan rakyat. Hal ini sejalan dengan hasil penelitian Awang, et al. (2002) bahwa dengan adanya dukungan, yaitu ketersedian lahan tegalan tanah kering cukup luas di Desa Ngaliyan, memberikan peluang untuk pengembangan hutan rakyat sengon. Namun kenyataannya, perkembangan hutan rakyat di Desa Sandingtaman mengalami stagnasi karena adanya perubahan fungsi lahan dan bencana alam.

Kenyataannya, telah terjadi perubahan lahan yang dimiliki responden mulai dari tahun 1983 - tahun 2007, dengan luas total sebesar $33.582 \mathrm{~m}^{2}$ (3,3582 ha). Keterangan yang lebih lengkap disajikan pada Tabel 3 . 
Tabel 3. Perubahan Lahan Responden di Desa Sandingtaman Tahun 1983-2007 Table 3. Respondent Land Change at Sandingtaman Vilage in 1983-2007

\begin{tabular}{|c|c|l|l|}
\hline No & $\begin{array}{c}\text { Total luas lahan } \\
\text { yang berubah } \\
\left(\mathrm{m}^{2}\right)\end{array}$ & \multicolumn{1}{|c|}{ Fungsi awalnya } & Berubah menjadi \\
\hline 1 & 9800 & Hutan rakyat & Kebun cabe \\
\hline 2 & 7980 & Hutan rakyat & Sawah \\
\hline 3 & 6540 & Hutan rakyat & Kandang ayam \\
\hline 4 & 2220 & Hutan rakyat & Rumah \\
\hline 5 & 1260 & Hutan rakyat & Kolam ikan \\
\hline 6 & 420 & Hutan rakyat & Pabrik heleran \\
\hline 7 & 2800 & Kebun singkong, sayuran & Hutan rakyat \\
\hline 8 & 2562 & Sawah & Hutan rakyat \\
\hline Total & 33582 & & \\
\hline
\end{tabular}

Sumber (Source) : Analisis data primer, 2008 (Primary data analysis, 2008)

Berdasarkan data pada Tabel 3 diketahui bahwa perubahan lahan yang paling banyak terjadi adalah dari lahan hutan rakyat menjadi lahan lainnya. Tersedianya teknologi tepat guna seperti tersedianya irigari (saluran air), memudahkan perubahan menjadi lahan pertanian (sawah) seluas $7980 \mathrm{~m}^{2}$. Walaupun ada juga perubahan yang awalnya lahan persawahan, berubah menjadi lahan hutan rakyat seluas $2562 \mathrm{~m}^{2}$, disebabkan air tidak dapat mengalir lagi ke lahan tersebut secara rutin.

Faktor lainnya adanya informasi budidaya tanaman yang lebih prospektif, dan keinginan meniru keberhasilan (succes story) budidaya jenis tanaman tertentu yang telah dilakukan pihak lain, sehingga lahannya berubah menjadi kebun cabe seluas $9800 \mathrm{~m}^{2}$, kandang ayam seluas $6540 \mathrm{~m}^{2}$, kolam ikan seluas $1260 \mathrm{~m}^{2}$ dan pabrik penggilingan padi (pabrik heleran) seluas $420 \mathrm{~m}^{2}$. Perubahan menjadi perumahan seluas $2220 \mathrm{~m}^{2}$ disebabkan tidak/belum memiliki rumah, juga karena adanya perpindahan lokasi perumahan, disebabkan bencana longsor pada tahun 1983 (Desa Sandingtaman, 2007).

Faktor gangguan binatang seperti monyet, menyebabkan petani merubah lahan kebun singkong/sayuran menjadi hutan rakyat seluas $2800 \mathrm{~m}^{2}$. Dengan demikian, menyusutnya luasan lahan hutan rakyat mayoritas disebabkan oleh tingginya tingkat kerawanan terhadap perubahan fungsi lahan, sebagai akibat tekanan ekonomi.

Terdapat pula beberapa luasan lahan hutan rakyat yang berpotensi (berpeluang) berubah menjadi peruntukan lainnya. Dari 34 responden yang memiliki hutan rakyat, hanya 8 orang $(23,53 \%)$ tetap akan mempertahankan hutan rakyatnya. Sedangkan 26 responden $(76,46 \%)$ menghendaki adanya perubahan pemanfaatan menjadi kegiatan lainnya. Responden yang menghendaki perubahan lahan (26 orang), sebanyak 22 orang $(64,70 \%)$ yang menginginkan adanya perubahan pemanfaatan lahan hutan rakyat, menjadi lahan pertanian. Alasannya adalah tanaman pertanian dapat langsung dikonsumsi. Demikian juga dengan 3 orang responden $(8,82 \%)$ yang menginginkan lahannya dijadikan sebagai kandang ayam, tetapi bagi 1 orang (2,94\%) yang akan membangun rumah alasannya adalah supaya anaknya dapat memiliki rumah. Keinginan perubahan ini masih 
sebatas potensi yang akan terwujud apabila berbagai kendala bisa diatasi. Kendala tersebut mencakup: aspek internal petani (faktor modal, tenaga kerja, teknologi, target waktu); dan aspek eksternal (faktor lingkungan). Adanya kendala tersebut memang membatasi pilihan, akan tetapi melalui perluasan pengetahuan dan ketrampilan, penggunaan peralatan, serta membangun aturan main berorganisasi sosial, maka kendalakendala tersebut dapat diatasi (Hardjanto, 2000). Jika kendala tersebut berhasil diatasi, maka hutan rakyat akan banyak yang berubah fungsinya. Perubahan ini dalam konteks ekonomi, dapat dipandang sebagai upaya masyarakat untuk meningkatkan manfaat/nilai ekonomi lahan demi peningkatan kesejahteraannya. Perubahan lahan menjadi peruntukan lain juga terjadi di Ponorogo, Wonogiri, Boyolali dan Bangkalan, dimana masyarakat yang sudah mengembangkan hutan rakyat kembali mengusahakan lahannya untuk usahatani semusim (Donie, 1996 dan Indrawati, et al., 1997 dalam Cahyono, et al., 2005).

\subsection{Bentuk Insentif Pengembangan Usaha Hutan Rakyat}

Hasil analisis teknik AHP pemilihan bentuk insentif disajikan dalam Gambar 1.

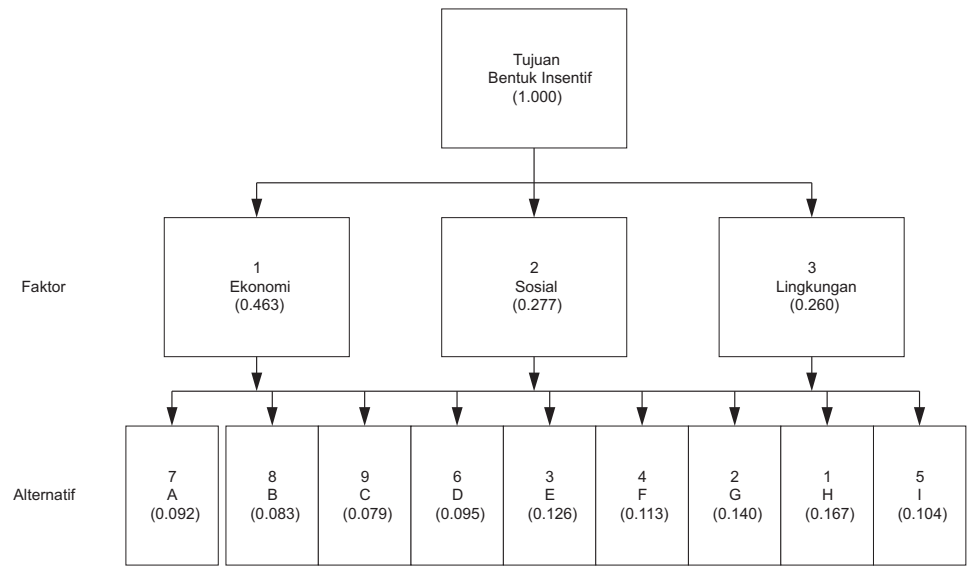

Gambar 1. Struktur Hirarki Bentuk Insetif Hutan Rakyat Figure 1. Hierarchy Struktur for Incentived form of privately owned forest

\section{Keterangan:}
A. Bantuan berupa input pertanian yaitu: bibit yang berkualitas, upah tenaga kerja, modal
B. Aksesbilitas terhadap lapangan pekerjaan
C. Fasilitas kredit sehingga dapat menciptakan lapangan pekerjaan baru (kredit usaha)
D. Pelayan sosial berupa sering dikunjungi oleh para pejabat sehingga petani merasa diperhatikan
E. Regulasi yang dapat memberikan keadilan, yaitu peraturan pemerintah yang lebih berpihak kepada petani, misalnya pengaturan perizinan bertata niaga kayu yang berkaitan dengan jenis tanaman.
F. Inisiasi dari pemerintah untuk membentuk kelompok mandiri, sehingga nantinya mampu mengatur hutan rakyat dalam siklus tebang dan tanam
G. Perda yang mendukung kemantapan tata guna lahan yang melindungi lingkungan dan kesejahteraan masyarakat desa
H. Penyuluhan yang tepat dan berlanjut baik tentang aspek teknis maupun manajemen, ekonomi, sosial, budaya
I. Subsidi mengenai infrastruktur publik yang diperlukan 
Berdasarkan jenis-jenis insentif terpilih, kemudian dilakukan analisis prioritas berdasarkan kepentingan relatif antar level dengan menggunakan software expert choise 9,0 for window. Prioritas stakeholders terhadap alternatif insentif yang ditawarkan diketahui pada tahapan wawancara dengan mempertimbangkan preferensi stakeholders terhadap faktor.

Hasil perhitungan bobot prioritas faktor memiliki rasio indeks konsistensi 0,0019 atau dibawah nilai batas rasio indeks konsistensi $(0,10)$, hal ini berarti bahwa bobot nilai yang diberikan oleh stakeholders telah memenuhi syarat kekonsistenan. Dari bobot nilai yang diberikan tersebut memberikan hasil urutan prioritas faktor yaitu: pertama adalah Ekonomi, mendapatkan nilai bobot tertinggi sebesar 0,463, selanjutnya Sosial mendapatkan nilai bobot urutan ke dua dengan nilai 0,277, serta Lingkungan mendapat nilai bobot sebesar 0,260. Nilai bobot ini menunjukkan urutan prioritas dalam implementasinya.

Selanjutnya berdasarkan preferensi narasumber stakeholders, dilakukan penilaian terhadap 9 alternatif insentif, yaitu dengan mempertimbangkan pengaruh penerapan insentif terhadap faktor. Urutan pemilihan bentuk insentif yang dapat dilakukan di hutan rakyat, berdasarkan preferensi stakeholders mulai dari yang paling utama sampai yang terakhir seperti diperlihatkan oleh Gambar 2.

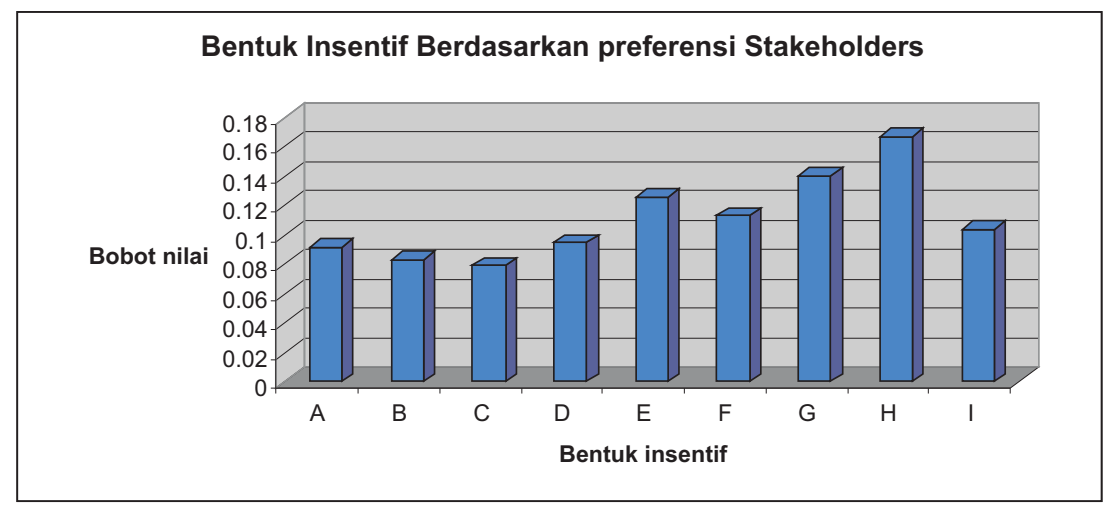

Gambar 2. Kurva Pemilihan bentuk insentif berdasarkan preferensi stakeholders Figure 2. Curve of Insentive choices based on stakeholders preferences

Berdasarkan urutan prioritas bentuk insentif yang dikehendaki oleh narasumber stakeholders, ternyata bentuk insentif yang mungkin diterapkan di Gunung Sawal adalah termasuk dalam insentif tidak langsung, dengan kondisi pemungkin (enabling condition) (Wijayanto, 2007). Berdasarkan hasil analisis tersebut, maka prioritas insentif yang diperlukan petani hutan rakyat di Gunung Sawal yang paling utama adalah perbaikan prakondisi (insentif tidak langsung), supaya nantinya bentuk insentif langsung dapat diimplementasikan secara efektif dan efisien.

Oleh karena itu bantuan yang lebih dibutuhkan adalah berupa insentif tidak langsung baik itu dari pihak pemerintah ataupun pihak lainnya, yang dapat mendorong 
pengembangan usaha hutan rakyat dan memungkinkan tumbuhnya inovasi (daya kreativitas) untuk perluasan pengusahaan hutan rakyat.

Pada bahasan kali ini akan difokuskan hanya pada tiga urutan prioritas insentif yang memiliki nilai bobot gabungan tertinggi dan menjadi prioritas, yaitu:

1. Penyuluhan yang tepat dan berlanjut baik mengenai aspek teknis maupun manajemen, ekonomi, sosial, budaya $(0,167)$. Diharapkan dengan adanya penyuluhan, maka akan terjadi transfer ilmu pengetahuan untuk meningkatkan kemampuan petani dalam membuat keputusan, tentang usaha-usaha pertanian/ kehutanan yang akan dilaksanakannya, sehingga terjadi keseimbangan antara kebutuhan ekonomi dengan pemeliharaan fungsi ekologinya. Insentif ini sesuai dengan karakteristik responden yang kebanyakan memiliki tingkat pendidikan tamat $\mathrm{SD}$, sehingga masih memerlukan pelatihan dan pendidikan yang berkaitan dengan pengelolaan usaha tani. Melalui penyuluhan, petani diharapkan akan mampu melakukan pengelolaan hutan rakyat yang mengarah pada peningkatan mutu tegakan dan meningkatkan daya kreativitas yang akhirnya mampu meningkatkan nilai finansial tegakannya.

2. Perda yang mendukung kemantapan tata guna lahan yang melindungi lingkungan dan kesejahteraan masyarakat desa $(0,140)$. Insentif ini sesuai dengan kondisi Desa Sandingtaman yang rawan bencana, sehingga diperlukan campur tangan pemerintah untuk membantu masyarakat, menentukan lokasi yang dapat dijadikan sebagai wilayah perumahan dan wilayah budidaya, sehingga petani terbantu dan mampu menentukan jenis tanaman yang sesuai dengan daya dukung tanah (carrying capacity) dan kondisi biofisiknya, serta diperoleh hasil yang optimal.

3. Regulasi yang dapat memberikan keadilan, yaitu peraturan pemerintah yang tidak diskriminatif, lebih berpihak kepada petani, misalnya pengaturan perizinan bertata niaga kayu yang berkaitan dengan jenis tanaman $(0,126)$. Untuk menjaga kelestarian hutan rakyat di sekitar Gunung Sawal, petani mengharapkan adanya peraturan pemerintah mengenai perizinan tata niaga kayu.

Jenis kayu yang dihasilkan petani cukup bervariasi, sebagian ada yang jenisnya sama dengan kayu yang di tanam atau dihasilkan dari kawasan. Jenis tanaman hutan yang ada di Desa Sandingtaman diantaranya adalah puspa (Schima wallicii), manglid (Maglieta glauca), kamper (Dryobalanops sp.), rasamala (Altingia excelsa), afrika (Meisopsis eminii), tisuk (Hibiscus macrophyllus), bambu (Bambusa sp.) dan lain-lain. Tanaman dominannya adalah sengon (Paraserianthes falcataria) dan mahoni (Swietenia macrophylla). Selain itu, letak hutan rakyat berdekatan/berbatasan dengan kawasan hutan negara. Untuk itu, peraturan atau kebijakan yang efisien dan bisa melindungi hak-hak petani secara berkeadilan sangat dibutuhkan.

Regulasi yang kondusif bisa lebih diartikan pada aspek aplikasi di lapangan. Pada saat ini masih terjadi praktek pelaksanaan peraturan di lapangan yang sangat beragam. Sebagian aparat masih menerapkan Instruksi Presiden Republik Indonesia No. 4 Tahun 2005 tentang illegal logging pada tataniaga kayu rakyat. Kondisi masyarakat yang lemah pada aspek pendidikan memberi kontribusi pada lemahnya aspek penguasaan informasi, termasuk dalam hal pengetahuan terhadap peraturan yang bisa diterapkan pada penatausahaan kayu. Pada sisi lain, masih cukup banyak aparat terkait, terutama yang ada 
di lapangan, belum memahami secara benar tentang jenis, perkembangan dan penerapan peraturan sesuai dengan kasusnya. Kedua kondisi tersebut menjadi "celah" bagi pihakpihak yang mempunyai kepentingan tertentu untuk mengambil keuntungan.

Berdasarkan Permenhut no P.33/Menhut-II/2007, jenis-jenis kayu dari hutan rakyat telah ditentukan dokumen yang sesuai. Untuk Kabupaten Ciamis, angkutan log mahoni harus dilengkapi dengan dokumen surat keterangan sahnya kayu bulat (SKSKB) dengan cap kr (Kayu Rakyat). Namun demikian karena jenis ini selain banyak dikembangkan masyarakat sekitar Gunung Sawal, juga banyak dikembangkan Perum Perhutani di kawasan yang sama (sekitar Gunung Sawal), maka pengawasan terhadap peredaran jenis ini menjadi lebih ketat, bahkan terkesan cenderung berlebihan karena sering menerapkan pembalakan liar. Secara psikologis, masyarakat merasa dicurigai seolah membawa kayu illegal jika peraturan tersebut yang selalu didahulukan. Akibatnya, jenis-jenis tertentu yang sama dengan jenis yang dikembangkan di hutan negara akan semakin dijauhi petani, dan akan semakin langka dipasar. Beberapa alasan terkait dengan kurang menariknya budidaya mahoni dari perspektif petani antara lain : 1) harga per satuan waktunya rendah, karena petani merasa menanam pohon mahoni perlu waktu tunggu yang sangat lama (sekitar 15 tahun), tetapi hasilnya dihargai murah oleh tengkulak dengan dalih tingginya biaya perizinan dan 2) ada biaya tambahan, karena pembeli kayu mahoni harus mengalokasikan sejumlah anggaran tambahan untuk memuluskan perjalanan kayu ke tempat tujuan. Namun dari perspektif tengkulak, usaha kayu mahoni masih menguntungkan mereka karena resiko seperti penambahan biaya-biaya lain di perjalanan mampu dialihkan pembebanannya ke petani, sehingga secara kumulatif harga kayu mahoni rakyat masih lebih murah dari Perum Perhutani. Dengan demikian, minat pasar untuk jenis mahoni masih cukup tinggi karena pembelian kayu ke petani masih berjalan terus lantaran tengkulak kayu masih menikmati keuntungan cukup tinggi. Jika tingginya permintaan pasar terhadap jenis ini tidak diimbangi dengan ketersediaan bahan baku di petani, maka kekosongan (gap) pasar akan benar-benar memicu terjadinya pembalakan liar jenis mahoni.

Penyerahan kewenangan perizinan ke kepala desa (surat keterangan asal usul/ SKAU) juga belum berjalan mulus. Sebagian besar kepala desa sambil menunggu mendapat kesempatan pelatihan untuk memperoleh sertifikat penerbit SKAU, dilakukan bimbingan oleh aparat kehutanan dalam hal penerbitan SKAU. Akan tetapi pada kenyataannya, masih banyak kepala desa yang tidak mengikuti proses transfer of knowledge tersebut, malahan cenderung banyak yang ingin terima jadi saja (tinggal tanda tangan dan terima komisi saja).

Oleh karena itu untuk menciptakan iklim usaha perkayuan rakyat, terutama yang terkait dengan jenis-jenis yang sama dengan yang dikembangkan di kawasan, pemerintah daerah Ciamis cq. Dinas Kehutanan Kabupaten Ciamis harus lebih aktif dan lebih intensif, melakukan koordinasi dengan aparat (instansi) terkait, serta sosialisasi dengan lembaga swadaya masyarakat (LSM) atau kelompok-kelompok tani, untuk menumbuhkembangkan pemahaman yang seragam terhadap persepsi, interpretasi dan aplikasi pelaksanaan penatausahaan hasil hutan dalam kaitannya dengan Instruksi Presiden Republik Indonesia No. 4 tahun 2005. Hal ini perlu dilakukan karena kecepatan perubahan (revisi) peraturan penata-usahaan kayu (rakyat), lebih cepat dari kecepatan 
pemahaman dan aplikasinya oleh aparat (instansi terkait) di lapangan. Sebagai contoh peraturan tentang SKAU, telah mengalami revisi cukup intensif (kurang dari setahun telah berubah) yakni dari P. 51/Menhut-II/2006 ke P.62/Menhut-II/2006 dan terbaru adalah P.33/Menhut-II/2007, dimana terjadi perubahan jenis-jenis kayu yang cukup substansial. Jenis kelapa yang dulunya harus menggunakan dokumen SKAU, kini cukup menggunakan nota penjualan. Status komersial suatu jenis kayu sangat ditentukan oleh permintaan pasar dan ketersediaan jenis substitusi, artinya jenis-jenis kurang dikenal (lesser known species) bisa menjadi komersial, jika teknologi yang terkait jenis tersebut telah berkembang, dan ketersediaan jenis utama semakin berkurang. Oleh karena itu status komersial kayu rakyat di pasar sangat dinamis, dan status pemberlakuan peraturan yang terkait jenis juga sangat dinamis, sehingga cenderung akan sering mengalami perubahan. Hal inilah yang harus menjadi pertimbangan pemerintah daerah Kabupaten Ciamis, untuk lebih mengintensifkan koordinasi dan sosialisasi peraturan dalam rangka membangun komitmen dalam menciptakan iklim usaha yang lebih kondusif yang berkeadilan.

Pemberian insentif ini melibatkan dua pihak yaitu pihak penerima insentif dan pihak yang memberikan insentif. Lebih jauh Wijayanto (2007) mengemukakan bahwa, insentif adalah semua bentuk dorongan spesifik atau rangsangan/stimulus, yang umumnya berasal dari faktor eksternal (pemerintah, LSM, swasta dan lain-lain), yang dirancang dan diimplementasikan untuk mempengaruhi atau memotivasi masyarakat, baik secara individu maupun kelompok, untuk bertindak atau mengadopsi teknik dan metoda baru yang bertujuan untuk memperbaiki kondisi.

Berdasarkan wawancara diketahui tujuan pemberian insentif adalah untuk memberikan kesejahteraan sosial dan pendapatan bagi masyarakat, menjamin kelestarian lingkungan (ekologi), meningkatkan kualitas SDM dan sebagai ibadah supaya mendapat pahala dari Allah SWT. Melalui insentif tersebut, diharapkan dapat memacu kegiatan pengusahaan hutan rakyat yang berdampak meningkatnya pendapatan serta kesejahteraan petaninya, dengan tetap menjaga kelestarian hutan rakyat sehingga kondisi lingkungan terjaga. Sedangkan keuntungan bagi pemberi insentif, yaitu supaya kesejahteraan petani meningkat dan menjamin kelestarian lingkungan. Kesejahteraan petani meningkat dengan cara perekonomian petani semakin baik, salah satunya diakibatkan oleh adanya pendapatan dari kegiatan hutan rakyat. Jika pendapatan petani meningkat maka petani memiliki kemampuan untuk meningkatkan daya beli, diantaranya dapat membayar pajak bumi dan bangunan (PBB). Hal ini sejalan dengan hasil penelitian Prastowo (1995) dalam Cahyono, et al. (2005), bahwa pengembangan hutan rakyat sebagai sarana perbaikan lingkungan hidup (environment), dengan memperhatikan kesejahteraan pemiliknya (prosperity), dan keamanan serta keutuhan hutan (security).

Mekanisme pemberian insentif, yaitu dapat diberikan langsung ke petani tetapi harus melalui kelompok, serta harus disertai dengan adanya peraturan yang jelas, yaitu system monitoring dan evaluasi (monev) secara periodik dan kontinyu untuk menjamin insentif tepat sasaran. Sebenarnya monitoring dan evaluasi ini dapat juga dilakukan oleh kelompok tani, namun sayangnya kelompok tani di Desa Sandingtaman ini sudah tidak aktif lagi, dan yang tersisa hanyalah nama kelompok saja. Sudah menjadi kebiasaan, kegiatan penyuluhan sering kali dilakukan melalui kelompok petani, dengan demikian maka keberadaan kelompok tani harus kembali diaktifkan. Pembentukan kelompok tani 
akan memudahkan pemerintah dalam melakukan monitoring, evaluasi dan pembinaan pengembangan hutan rakyat.

\section{KESIMPULAN DAN SARAN}

\subsection{Kesimpulan}

1. Faktor-faktor yang berpotensi memicu terjadinya perubahan lahan hutan rakyat menjadi fungsi lainnya, antara lain perkembangan dan ketersediaan : a). teknologi tepat guna, b). informasi budidaya tanaman yang lebih prospektif, c). adanya keinginan meniru keberhasilan (succes story) budidaya jenis tanaman tertentu yang telah dilakukan pihak lain, d). karakteristik petani pemilik hutan rakyat, dan e). kondisi given Desa Sandingtaman yang rawan bencana alam. Potensi perubahan fungsi lahan tersebut sebenarnya tidak akan terwujud jika kendala seperti : target waktu, teknologi, modal, tenaga kerja dan lingkungan, belum mendukung. Akan tetapi dengan tersedianya/perkembangan pengetahuan penggunaan peralatan, keterampilan, serta membangun aturan main berorganisasi sosial, maka kendala-kendala tersebut berpotensi untuk teratasi.

2. Berdasarkan analisis metoda AHP bentuk insentif yang sesuai dengan petani di wilayah Gunung Sawal adalah perbaikan prakondisi (insentif tidak langsung), untuk membenahi kondisi sosial masyarakat terlebih dahulu, supaya bentuk insentif langsung nantinya dapat diimplementasikan secara efektif dan efisien. Mekanisme penyampaian insentif melalui kelompok tani.

\subsection{Saran}

1. Dalam rangka program pemberian insentif pengembangan hutan rakyat di wilayah Gunung Sawal, hasil penelitian ini dapat diadopsi oleh Dinas Kehutanan Ciamis, dengan catatan pada penyampaian program-program yang melibatkan masyarakat harus memperhatikan kondisi karakteristik masyarakat setempat.

2. Pemerintah daerah sebaiknya melakukan upaya untuk menekan kecenderungan perubahan fungsi lahan dari hutan rakyat ke fungsi lainnya, dengan mengatasi penyebab utama perubahan tersebut. Salah satunya adalah tekanan ekonomi yang sangat mendesak yang mana saat ini tidak bisa dipenuhi dari hutan, tetapi dipahami bisa dipenuhi dari sektor lain seperti pertanian, peternakan, perikanan dan lain lain. Oleh karena itu, kebutuhan tersebut harus bisa dipenuhi dengan cara menambah ketersediaan lapangan pekerjaan yang lebih beragam, sehingga masyarakat bisa memilih jenis pekerjaan yang sesuai dengan ketrampilannya. Oleh karena itu, pemerintah daerah harus menyesuaikan arah pembangunan, dengan lebih memprioritaskan pembangunan sektor-sektor penggerak ekonomi di desa dan atau melakukan "urbanisasi desa". 


\section{DAFTAR PUSTAKA}

Anonimous. 2009. Prospek Hutan Rakyat untuk Industri Perkayuan Nasional. Website http://www.mediadata.co.id/Multi-Client-Studies/MCS-Indonesian-Edition. Diakses tanggal 14 April 2009.

Awang, S.A., W. Andayani, B. Himmah, W. T. Widayanti dan A. Affianto. 2002. Hutan Rakyat. Sosial Ekonomi dan Pemasaran. BPFE. Yogyakarta.

Awang, S.A., E. B. Wiyono dan S. Sadiyo. 2007. Unit Manajemen Hutan Rakyat: Proses Konstruksi Pengetahuan Lokal. Banyumili Art Network, Sleman.

Badan Pusat Statistik Provinsi Jawa Barat. 2007. Penyusunan Data Basis Indeks Pembanguan Manusia (IPM) Provinsi Jawa Barat Tahun 2007. Kerjasama Badan Perencanaan Daerah Provinsi Jawa Barat dengan Badan Pusat Statistik Provinsi Jawa Barat. Website http://www.bapedajabar.go.id/bapeda_design/docs/ publikasi_data/20080409_141711.pdf. Diakses tanggal13 April 2009.

Cahyono, A.S., N.P. Nugroho dan N.A. Jariyah. 2005. Tinjauan Faktor Kelayakan, Keuntungan dan Kesinambungan Pada Pengembangan Hutan Rakyat. Info Sosial Ekonomi. Vol. 5 (2) tahun 2005. Puslit Sosek Dan Kebijakan Kehutanan. Badan Litbang Kehutanan Departemen Kehutanan, Bogor.

Desa Sandingtaman. 2007. Format Laporan Profil Desa dan Kelurahan. Tingkat Desa dan Kelurahan. Direktorat Jenderal Pemberdayaan Masyarakat dan Desa. Departemen Dalam Negeri.

Diniyati, D., E. Fauziyah, T.Sulistyawati, B. Achmad., A. Badrunasar, Suyarno, dan E. Mulyati. 2006. Kajian Sosial Ekonomi Budaya dan Jasa Hutan Lindung Di Suaka Margasatwa Gunung Sawal. Laporan Penelitian. Loka Litbang Hutan Moonson Ciamis. Tidak Diterbitkan.

Dinas Kehutanan Ciamis. 2006. Buku masterplan pembangunan bidang kehutanan Kabupaten Ciamis Jawa Barat Pemerintah Kabupaten Ciamis Dinas Kehutanan Ciamis, Ciamis.

Hardjanto. 2000. Beberapa Ciri Pengusahaan Hutan Rakyat di Jawa. Dalam : Hutan Rakyat Di Jawa Perannya dalam Perekonomian Desa. Penyunting Didik Suharjito. Program Penelitian dan Pengembangan Kehutanan Masyarakat (P3KM). Fakultas Kehutanan IPB, Bogor.

Herawati, T. 2001. Pengembangan Sistem Pengambilan Keputusan dengan Kriteria Ganda dalam Penentuan Jenis Tanaman Hutan Rakyat. Contoh Kasus di Kabupaten Ciamis Jawa Barat. Thesis. Program Pascasarjana. IPB. Bogor. Tidak diterbitkan.

Instruksi Presiden Republik Indonesia No. 4 Tahun 2005. Tentang Pemberantasan Penebangan Kayu Secara Illegal di Kawasan Hutan dan Peredarannya di Seluruh Wilayah Republik Indonesia. Tanggal 18 Maret 2005. 
Peraturan Menteri Kehutanan. Nomor: P.33/Menhut-II/2007. Perubahan Kedua Atas

Peraturan Menteri Kehutanan Nomor P. 51/Menhut-II/2006 Tentang Penggunaan Surat Keterangan Asal Usul (SKAU) Untuk Pengangkutan Hasil Hutan Kayu yang Berasal dari Hutan Hak.

Purnama, B.M. 2009. Pembangunan Kehutanan Indonesia. Rapat Koordinasi Perencanaan Pembangunan Kehutanan di Bandung. Sekretaris Jendral Departemen Kehutanan, Jakarta.

Purwanto., S. E. Wati dan S. A. Cahyono. 2004. Kelembagaan untuk mendukung pengembangan hutan rakyat produktivitas tinggi. Prosiding Ekspose Terpadu Hasil Penelitian, Yogyakarta 11-12 Oktober 2004. Hal 53-65. Puslitbang Bioteknologi dan Pemuliaan Tanaman Hutan, Yogyakarta.

Wijayanto, N. 2007. Insentif Pengusahaan Hutan Rakyat. Makalah disampaikan pada Seminar Pengembangan Hutan Rakyat Mendukung Kelestarian Kayu Rakyat di Pusat Penelitian Sosial Ekonomi Dan Kebijakan Kehutanan (PUSLITSOSEK) Bogor, pada tanggal 3 Desember 2007. 